\title{
WHEAT IRRIGATION SCHEDULING USING INFRARED THERMOMETER
}

\author{
M.M. Attia ${ }^{(1)}$, A.A. Sallam ${ }^{(1)}$ and E. Ghalab(2) \\ (1) Soils, Water and Environment Res. Inst. A.R.C. \\ (2) Field Crops Res. Inst. A.R.C.
}

Received: Oct. 18,2017

Accepted: Oct. 31, 2017

\begin{abstract}
A field experiment was conducted at Nubaria Agricultural Research Station (calcareous sandy loam soil),30.900 E, $29.960 \mathrm{~N}$, and $25 \mathrm{~m}$ above sea level, El-Behiera governorate, Egypt, in the two successive seasons of 2013-2014 and 2014-2015 to assess the suitability of using infrared thermometer in irrigation scheduling of wheat crop, and to determine the effect of irrigation treatments on wheat grain and straw yields, water consumptive use, amounts of applied water, stress index and water utilization efficiency. Three irrigation treatments, based on the temperature difference $(d t)$ between air ( $T a)$ and canopy $(T c)$, were adopted to accomplish the tested objectives. The irrigation treatments were, $\iota_{1}$ irrigating when the difference between the canopy temperature $(T C)$, and air temperature $(T a)=-1{ }^{\circ} \mathrm{C}, I_{2}$ irrigating when $T c-T a$ $=0{ }^{\circ} \mathrm{C}$ and $\mathrm{I}_{3}$, irrigating when $\mathrm{TC}-\mathrm{Ta}=+1^{\circ} \mathrm{C}$. Results revealed that maximum grain and straw, wheat yields were produced when irrigating at $d t=-1{ }^{\circ} \mathrm{C}$, in two growing seasons. The total amounts of applied irrigation water for wheat crop were 42.1, 36.5 and $29.7 \mathrm{~cm}$ for $I_{1}, I_{2}$ and $I_{3}$ treatments, respectively, in first season, and were $41.7,36.1$ and $30.6 \mathrm{~cm}$ for the same respective treatments, in the second season. The seasonal water consumption were $32.4,26.8$ and $21.2 \mathrm{~cm}$ for $I_{1}, I_{2}$ and $l_{3}$ treatments, respectively in the first season, whilein the second season, the values were $30.3,25.3$ and $20.0 \mathrm{~cm}$ for the same treatments, respectively. The highest values of stress index were recorded with $I_{3}$ and $I_{2}$ irrigation treatments, while, the lowest value was recorded with $I_{1}$ tratment. The highest values of water utilization efficiency (1.68 and $1.93 \mathrm{Kg}$ grain per $\mathrm{m}^{3}$ applied irrigation water) were obtained by $\mathrm{l}_{1}$ treatment $\left(d t=-1{ }^{\circ} \mathrm{C}\right)$. in the first and second seasons, respectively. The obtained results allowed us to conclude that infrared thermometer can be used as an easy tool for scheduling irrigation of wheat crop based on the measurements of canopy and air temperatures.
\end{abstract}

Key words: Infrared thermometer -Stress Index - Irrigation scheduling - wheat

\section{INTRODUCTION}

The use of infrared thermometer to measure canopy temperature for irrigation scheduling purposes has been successfully applied in arid region, but it had complications in humid areas where the vapor pressure deficit is low. When plantsare under water stress, thiscauses stomatal closure, which interrupts energy dissipation and results in the rise of leaf temperature. The leaf or canopy temperature is used as an indicator of plant water stress (Jackson et al., 1981) and Jackson (1982). Blum et al., (1989) indicated the suitability of canopy temperature depression as an indicator of yield and stress tolerance prediction. However, it must be evaluated for every individual environment and inparticular for every plant species. Guofa et al., (2004) reported a significant correlation between canopy temperature and wheat grain yield which may appear under severe water stress, and suggested further experiments onto study root uptake. Orta et al., (2004), conducted a study, in Turkey, to develop baseline equations which can be used to quantify and evaluate crop water stress index of three winter wheat genotypes, and to schedule irrigation and to predict yield. Jalali-Farahani et al., (1993), showed that changes in crop water stress index (CWSI) depended on the applied irrigation volume. Bijanzadeh and Emam (2012), reported that 
maximum wheat grain yield was obtained in shiraz and Yavaroscultivars under well and excess watering and crop water stress index (CWSI) in these cultivars ranged from 0.31 to 0.36 , whereas by decreasing water supply and increasing CWSI, grain yield in these cultivars decreased significantly. Reynolds et al., (2007), indicated that canopy temperature is phenotypically and genetically associated with grain yield under drought stress. Inagaki and Nachit (2008), indicated that the canopy temperature difference of approximately $7^{\circ} \mathrm{C}$, is large enough to visually detect transpiration changes in foliage and distantly monitor the soil water stress during plant growth. They concluded that, infrared thermography has great potential as a tool to instantly monitor water stress in fields. Ehsan and Yahya (2012) found that, maximum wheat grain yield was obtained, in Shiraz and Yavaros cultivars, under well and excess watering. They indicated also that, the canopy temperature reflects the interactions among plants, soil, and atmosphere. The application of canopy - air temperature difference was appropriate for crop water stress determination as it is non-contact, reliable;provide considerably precise estimation and represents actual crop water demand. Abdolreza et al., (2014) indicated that, the index of difference between the temperature of air and leaf ( $\Delta T=$ Tair - Tleaf) showed the leaf temperature which could indicate the amount of water absorbed by the root. Thus, leaf temperature can be widely used as an effective indicator of the estimated timing of irrigation. Kim et al., (2015) found that the values of Tc- Ta was negatively related to vapor pressure deficit (VPD). Further, cucumber growth in the under and over irrigated field, showed water stress in contrast to that grown in the optimally irrigated field. They concluded that, thermal infrared measurements could be useful for evaluating crop water status and plays an important role in irrigation scheduling of agricultural crops.

The main objectives of this study are to assess the suitability of using the infrared thermometer in irrigation scheduling of wheat crop, and to determine the effect of irrigation treatments on wheat grain and straw yields, water consumptive use, amounts of applied water, stress index and water utilization efficiency.

\section{MATERIALS AND METHODS}

A field experiment was conducted at Nubaria Agricultural Research Station (calcareous sandy loam soil) (30.900 E, $29.960 \mathrm{~N}$, and $25 \mathrm{~m}$ above sea level), ElBehiera governorate, Egypt, in the two successive winter seasons of 2013-2014 and 2014-2015. Soil samples were collected before sowing to determine main soil physical and chemical characters (Page et al., 1982) and some soil hydro-physical parameters. The values of the measured parameters are presented in Tables 1 and 2 .

Table 1: Field capacity, wilting point, available soil moisture and bulk density of the soil at the experimental site.

\begin{tabular}{|c|c|c|c|c|}
\hline $\begin{array}{c}\text { Soil depth } \\
(\mathrm{cm})\end{array}$ & $\begin{array}{c}\text { Field Capacity } \\
(\%)\end{array}$ & $\begin{array}{c}\text { Wilting Point } \\
(\%)\end{array}$ & $\begin{array}{c}\text { Available water } \\
(\%)\end{array}$ & $\begin{array}{c}\text { Bulk } \\
\text { density }\left(\mathrm{gcm}^{-3}\right)\end{array}$ \\
\hline $0-15$ & 27.1 & 15.0 & 12.1 & 1.08 \\
\hline $15-30$ & 25.8 & 13.4 & 12.4 & 1.15 \\
\hline $30-45$ & 23.0 & 12.8 & 10.2 & 1.17 \\
\hline $45-60$ & 21.3 & 11.8 & 9.5 & 1.27 \\
\hline Average & 24.3 & 13.3 & 11.0 & 1.16 \\
\hline
\end{tabular}


Table 2: Chemical analysis of the soil at the experimental site.

\begin{tabular}{|c|c|c|c|c|c|c|c|c|c|c|c|c|}
\hline $\begin{array}{c}\text { Soil } \\
\text { depth } \\
(\mathrm{cm})\end{array}$ & $\begin{array}{c}\text { Total } \\
\mathrm{N} \%\end{array}$ & \multicolumn{2}{|c|}{$\begin{array}{c}\text { Available } \\
\mathrm{Mg} / \mathrm{g}\end{array}$} & \multicolumn{4}{|c|}{$\begin{array}{c}\text { Soluble cations } \\
(\mathrm{meq} / \mathrm{l})\end{array}$} & \multicolumn{3}{|c|}{$\begin{array}{c}\text { Soluble anions } \\
(\mathrm{meq} / \mathrm{l})\end{array}$} & $\mathrm{pH}$ & $\mathrm{EC}$ \\
& & $\mathrm{K}$ & $\mathrm{P}$ & $\mathrm{K}^{+}$ & $\mathrm{Na}^{+}$ & $\mathrm{Mg}^{++}$ & $\mathrm{Ca}^{++}$ & $\mathrm{Cl}^{-}$ & $\mathrm{SO}_{4}^{--}$ & $\mathrm{HCO}_{3}^{-}$ & & \\
\hline $0-30$ & 0.07 & 105 & 3.2 & 0.70 & 6.39 & 1.80 & 8.30 & 9.30 & 2.82 & 5.00 & 8.30 & 1.73 \\
\hline $30-60$ & 0.09 & 80 & 2.3 & 0.72 & 6.25 & 1.30 & 7.20 & 9.20 & 2.50 & 4.10 & 8.50 & 1.56 \\
\hline
\end{tabular}

A randomized completely blocks design (RCBD) with four replicates was used. Three irrigation treatments were applied, the irrigation treatments were, $l_{1}$ : irrigating when the difference (dt) between the canopy temperature $(\mathrm{Tc})$ and air temperature $(\mathrm{Ta})=-$ $1^{\circ} \mathrm{C}$. I2: irrigating when $\mathrm{TC}-\mathrm{Ta}=0{ }^{\circ} \mathrm{C}$, and $\mathrm{I}_{3}$ : irrigating when $\mathrm{Tc}-\mathrm{Ta}=+1{ }^{\circ} \mathrm{C}$. All irrigation treatments were applied after the $1^{\text {st }}$ irrigation.

The total number of the experimental plots were 12 plot. The area of the plot was $42 m^{2}$. (7m long $\times 6 m$ width).

Canopy and air temperatures and stress index reading were measured during midday every two days using the scheduler plant stress monitor (Standard Oil Engineered Materials Company, 1987). In the field, the monitor compares plant temperature to its total environment, measuring and analyzing: relative humidity, air temperature, plant temperature, and sunlight intensity. The interpretation of the Stress Index readings are given as follows:

$$
\begin{gathered}
\text { Stress } \leq 0 \text { Plant is extremely well irrigated } \\
\text { Index } 0-2 \text { Plant is operating at top efficiency } \\
\text { Reading }>2 \text { Cause plant performance to suffer }
\end{gathered}
$$

Wheat grains (Giza 168 Varity) were sown on the $20^{\text {th }}$ and $25^{\text {th }}$ of November and were harvested on the $19^{\text {th }}$ and $14^{\text {th }}$ of Mayin the first and second seasons, respectively. Yield data were obtained from central area of each plot (30 $\mathrm{m}^{2}, 6 \mathrm{~m}$ long $\times 5 \mathrm{~m}$ width) to avoid any border effects. Fertilization practices included the application of $30 \mathrm{Kg} \mathrm{P}_{2} \mathrm{O}_{5} / \mathrm{fed}$ (as calcium super phosphate, 15\%), $24 \mathrm{Kg} \mathrm{K}{ }_{2} \mathrm{O} / \mathrm{fed}$ (as potassium sulphate, $48 \%$ ), and $100 \mathrm{Kg} \mathrm{N} / \mathrm{fed}$ (as ammonium nitrate, 33.5\%).

Soil moisture contents were determined gravimetrically as average of four samples per plot taken at 0-15, 15-30, 30-45, and 45$60 \mathrm{~cm}$ depth just before and two days after each irrigation to determine water consumption. Irrigation water was applied to raise the soil moisture irrigation to field capacity. An extra amount of $20 \%$ of applied water was added to each plot to insure distribution uniformity of water and for leaching requirements. The irrigation water delivered to field plots was measured by using a water flow meter connected to an irrigation pump placed very close to the experimental plots to ensure high water application efficiency. The total depths of the rainfall precipitated at the experimental site were 78.2 and $108.9 \mathrm{~mm}$ in the first and second season, respectively (Table 3 ).

Water consumption (CU) and depth of irrigation water (DIW) were calculated according to equations of Hansen et al. (1974).

$$
\begin{aligned}
\mathrm{CU} & =\sum_{i=1}^{i-4} \frac{\theta 1-\theta 2}{100} \times D b \times d \quad c m \\
\mathrm{DIW} & =\sum_{i=1}^{i-4} \frac{F \cdot c-\theta 2}{100} \times D b \times d \quad \mathrm{~cm}
\end{aligned}
$$

The applied of irrigation water (AIW) were calculated as follows:

$$
A I W=\frac{D I W}{E a(1-L R)}
$$


M.M. Attia, et al.,

Table 3. Precipitation( $\mathrm{mm}$ ) during the $2013 / 2014$ and $2014 / 2015$ growing seasons.

\begin{tabular}{|l|c|c|}
\hline Season & $2013 / 2014$ & $2014 / 2015$ \\
\hline Month & Precipitation $(\mathrm{mm})$ & Precipitation $(\mathrm{mm})$ \\
\hline Nov. & 7.8 & 10.3 \\
\hline Dec. & 19.5 & 27.6 \\
\hline Jan. & 19.8 & 29.9 \\
\hline Feb. & 13.2 & 21.1 \\
\hline Mar. & 11.1 & 17.1 \\
\hline Apr. & 6.8 & 2.9 \\
\hline Total & 78.2 & 108.9 \\
\hline
\end{tabular}

where:

$\mathrm{FC}=\%$ of field capacity

$\Theta_{1}=\%$ of soil moisture content after irrigation.

$\Theta_{2}=\%$ of soil moisture content before irrigation.

$\mathrm{d}=$ Soil depth in $(\mathrm{cm})$.

$\mathrm{D}_{\mathrm{b}}=$ Soil bulk density $\left(\mathrm{gm} \mathrm{cm}^{-3}\right)$.

$\mathrm{i}=$ number of soil layer.

LR $=$ Leaching requirement (addition of $20 \%$ of AIW in the calcareous soil).

$\mathrm{Ea}=$ Application efficiency $\approx 70 \%$ for the control surface irrigation system.

Water utilization efficiency (WUTE) was calculated according to Jensen (1983).

$$
W U_{t} E=\frac{\text { wheat grain yield }(\mathrm{kg} / \mathrm{fed})}{\text { water applied }\left(\mathrm{m}^{3} / \mathrm{fed}\right)}
$$

The obtained data were statistically analyzed according to the technique of analysis of variance (ANOVA) for the simple design as described by Steel and Torrie (1980). Means were separated using the least significant different (L.S.D) method.

\section{RESULTS AND DISCUSSION}

\section{1- Wheat grain and straw yields:}

Grain and straw yields of wheat crop for the two growing seasons are presented in Table 4. The results indicated that all tested traits were significantly affected by irrigation treatments.
The highest values of grain and straw yields obtained when irrigated under the $I_{1}$ treatment, in the first and second seasons, while the lowest values were recorded for $I_{3}$ treatment, in the two growing seasons. Results showed also that, the grain and straw wheat yields for $I_{1}$ irrigation treatment were 49.1 , and $17.2 \%$, and were 47.0 and $13.9 \%$, higher than those obtained from the $I_{3}$ treatment in the $1^{\text {st }}$ and $2^{\text {nd }}$ growing seasons respectively. These results are agreement with the results of Guofa et al., (2004), Reynolds et al., (2007) and Ehsan and Yahya (2012).

\section{2- Applied irrigation water (AIW):}

Monthly and total of applied irrigation water for wheat in the first and second seasons are given in Table 5 . The results showed that, for each irrigation treatment the data for both seasons were almost the same. The seasonal of applied irrigation water were 42.1 and $41.7 \mathrm{~cm}$ for $I_{1}$ treatment while they were 29.7 and $30.6 \mathrm{~cm}$ for $\mathrm{I}_{3}$ treatments in the two growing seasons, respectively. The applied irrigation water for wheat crop were close agreement with that reported by Attia (1989) who found that the water requirement was $38.4 \mathrm{~cm}$, for the best irrigation treatment (irrigation at $75 \%$ depletion of available water). Also, these results are agreement with the results of Abdolreza et al., (2014). 
Table 4: Means of wheat grain and straw yields (ton/ha) as affected by irrigation treatments during the 2013/2014 and 2014/2015 winter growing seasons.

\begin{tabular}{|l|c|c|c|c|}
\hline \multirow{2}{*}{ Treatments } & \multicolumn{2}{|c|}{ Grain yield } & \multicolumn{2}{c|}{ Straw yield } \\
\cline { 2 - 5 } & $\begin{array}{c}2013 / 2014 \\
\text { season }\end{array}$ & $\begin{array}{c}2014 / 2015 \\
\text { season }\end{array}$ & $\begin{array}{c}2013 / 2014 \\
\text { season }\end{array}$ & $\begin{array}{c}2014 / 2015 \\
\text { season }\end{array}$ \\
\hline $\mathrm{I}_{1}$ & 7.08 & 8.08 & 14.75 & 14.33 \\
\hline $\mathrm{I}_{2}$ & 6.08 & 6.50 & 13.58 & 12.83 \\
\hline $\mathrm{I}_{3}$ & 4.75 & 5.50 & 12.58 & 12.58 \\
\hline L.S.D at 5\% & 0.45 & 0.72 & 0.82 & 2.22 \\
\hline
\end{tabular}

Table 5. Monthly and total applied irrigation water $(\mathrm{cm})$ for wheat crop as affected by irrigation treatments during the 2013/2014 and 2014/2015 growing seasons.

\begin{tabular}{|c|c|c|c|c|c|c|c|c|c|c|c|c|}
\hline Season & \multicolumn{6}{|c|}{$2013 / 2014$} & \multicolumn{6}{|c|}{$2014 / 2015$} \\
\hline \multirow{2}{*}{ 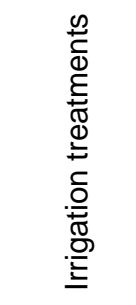 } & \multicolumn{6}{|c|}{ Irrigation date } & \multicolumn{6}{|c|}{ Irrigation date } \\
\hline & 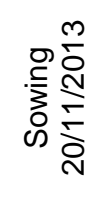 & 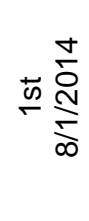 & 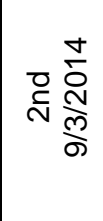 & ㅎํㅇ $\frac{\stackrel{d}{\stackrel{N}{N}}}{\stackrel{m}{N}}$ & 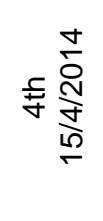 & $\begin{array}{l}\overline{\frac{\pi}{0}} \\
\stackrel{0}{\circ}\end{array}$ & . & 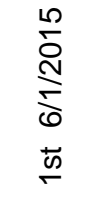 & 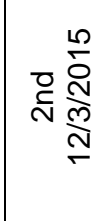 & 을 $\frac{\stackrel{n}{N}}{\frac{N}{m}}$ & 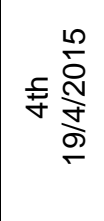 & $\begin{array}{l}\text { त्ञ } \\
0 \\
0\end{array}$ \\
\hline$I_{1}$ & 12.30 & 6.50 & 10.40 & 6.20 & 6.70 & 42.10 & 11.50 & 6.80 & 11.10 & 5.50 & 6.80 & 41.70 \\
\hline 2 & 12.30 & 6.50 & - & 10.00 & 7.70 & 36.50 & 11.50 & 6.80 & - & 10.30 & 7.50 & 36.10 \\
\hline 13 & 12.30 & 6.50 & - & -- & 10.90 & 29.70 & 11.50 & 6.80 & - & - & 12.30 & 30.60 \\
\hline
\end{tabular}

\section{3- Stress index (SI)}

Canopy and air temperatures and Stress Index for the two growing seasons are given in Figures 1 and 2. Results indicated that the highest Stress Index values of 6.5 and 6.9 were recorded for irrigation treatment lis the $1^{\text {st }}$ and $2^{\text {nd }}$ growing seasons, respectively. While, the lowest values (less than 2.9) were recorded with irrigation treatment $I_{1}$ in the two growing seasons. The results indicated that, wheat plants under $l_{3}$ irrigation treatment were under severe stress (6.5-6.9) which resulted in significant yield reduction. Results showed also that the Stress Index values were higher than 3(3.2-3.5) with $\|_{2}$ irrigation treatment in the two seasons, indicating moderate stress on wheat plants. The obtained results were in agreement with Jalali-Farahani et al., |(1993) and Bijanzadeh and Emam (2012).

\section{4- Water consumption (CU):}

Water consumption as determined by soil moisture depletion during the two growing seasons are given in Table 6 . The water consumption were $32.4,26.8$ and $21.2 \mathrm{~cm}$ for the irrigation treatments $I_{1}, I_{2}$ and $I_{3}$, respectively, in the first season, while in the second season the values were 30.3, 25.3 and $20.0 \mathrm{~cm}$ for the previous treatments, respectively. These results are in agreement with the results of Abdolreza et al., (2014).

\section{5- Water Utilization Efficiency (WUTE):}

Results in Table 7 represent the effect of irrigation treatments on water utilization efficiency (WUTE) expressed as $\mathrm{Kg}$ of wheat grain yield per cubic meter $\left(\mathrm{m}^{3}\right)$ of applied irrigation water. The highest values of WUTE were scored by $I_{1}$ treatment in the two growing seasons, while the lowest values 
were obtained by $I_{3}$ treatment in the two growing seasons. These results varied from 1.59 to 1.68 and 1.79 to $1.93 \mathrm{Kg}$ wheat grain yield per $\mathrm{m}^{3}$ applied irrigation water for first and second seasons, respectively.
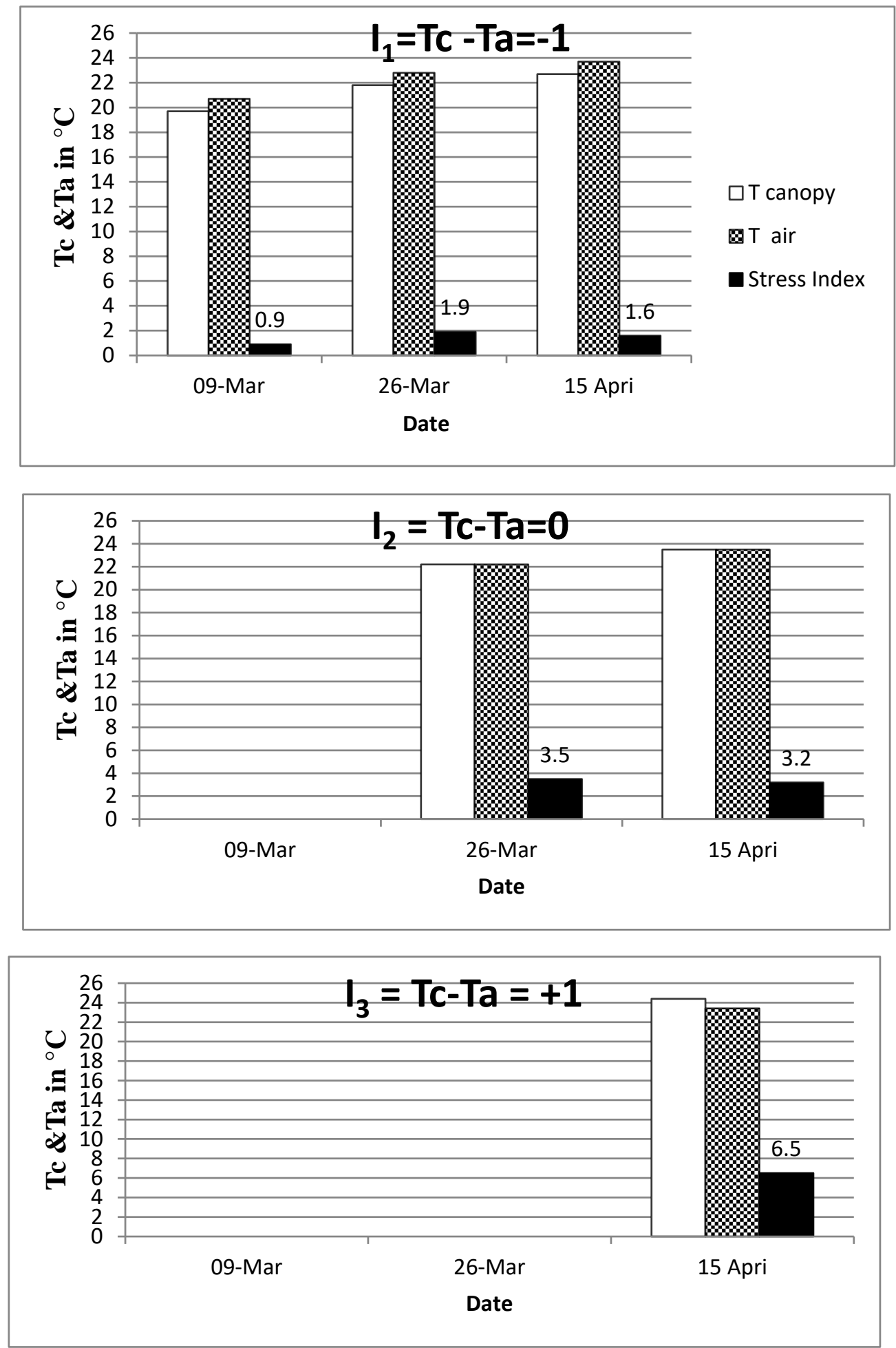

Fig. 1. Irrigation treatments and Stress Index during 2013-2014 growing season. 

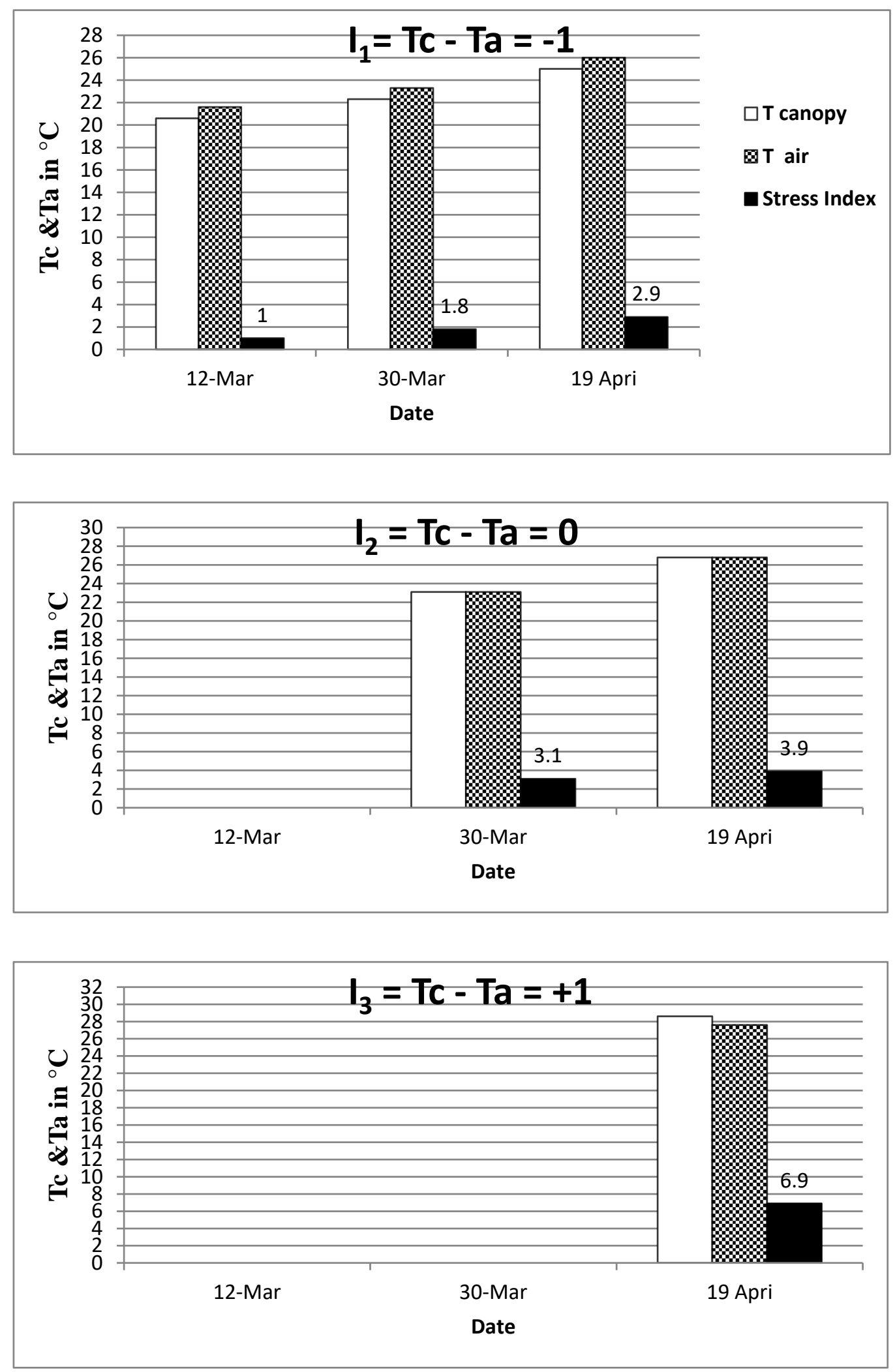

Fig. 2: Irrigation treatments and Stress Index during 2014-2015 growing season. 
M.M. Attia, et al.,

Table 6. Water consumption (cm)by wheat crop as affected by irrigation treatments during 2013/2014 and 2014/2015 growing seasons.

\begin{tabular}{|c|c|c|c|c|c|c|c|c|c|c|c|c|}
\hline \multirow[b]{3}{*}{ 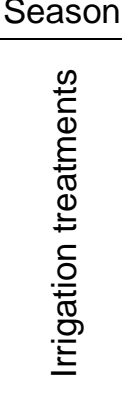 } & \multicolumn{6}{|c|}{$2013 / 2014$} & \multicolumn{6}{|c|}{$2014 / 2015$} \\
\hline & \multicolumn{6}{|c|}{ Irrigation period } & \multicolumn{6}{|c|}{ Irrigation period } \\
\hline & 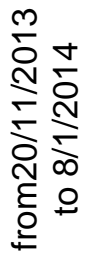 & 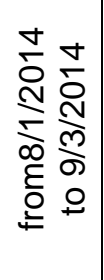 & 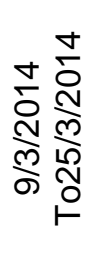 & 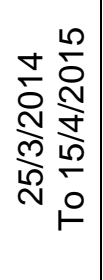 & 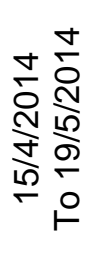 & 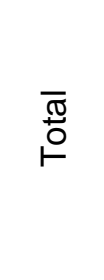 & 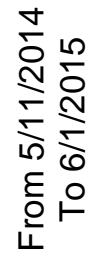 & 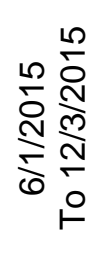 & 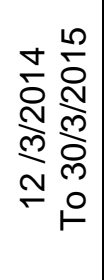 & 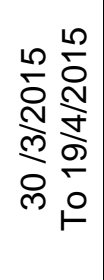 & 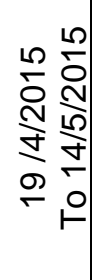 & $\underset{\ominus}{\bar{\sigma}}$ \\
\hline$I_{1}$ & 5.80 & 6.10 & 6.80 & 6.80 & 6.90 & 32.40 & 5.60 & 5.60 & 6.50 & 6.60 & 6.00 & 30.30 \\
\hline $\mathrm{I}_{2}$ & 6.00 & - & 6.90 & 6.90 & 7.00 & 26.80 & 5.90 & - & 6.80 & 5.80 & 6.80 & 25.30 \\
\hline$I_{3}$ & 6.10 & - & - & 7.60 & 7.50 & 21.20 & 5.80 & - & - & 6.90 & 7.30 & 20.00 \\
\hline
\end{tabular}

Table 7: Water Utilization Efficiency (WUTE) in $\mathrm{Kg}$ wheat grain yield per $\mathrm{m}^{3}$ applied irrigation water as affected by irrigation treatments during 2013/2014 and 2014/2015 growing seasons.

\begin{tabular}{|l|c|c|}
\hline \multirow{2}{*}{ Treatments } & \multicolumn{2}{|c|}{ Water Utilization Efficiency (WUtE) } \\
\cline { 2 - 3 } & Season 2013/2014 & Season 2014/2015 \\
\hline $\mathrm{I}_{1}$ & 1.68 & 1.93 \\
\hline $\mathrm{I}_{2}$ & 1.66 & 1.80 \\
\hline $\mathrm{I}_{3}$ & 1.59 & 1.79 \\
\hline
\end{tabular}

\section{CONCLUSIONS}

From the obtained results it could be concluded that:

1- Wheat grain yield is better if the watering is scheduled to keep the $\mathrm{dt}=-1^{\circ} \mathrm{C}$.

2- The soil moisture is higher when $\mathrm{dt}=-1^{\circ} \mathrm{C}$

3- The water utilization efficiency (WUTE) is higher when $\mathrm{dt}=-1{ }^{\circ} \mathrm{C}$

4- The highest values of stress index were recorded when $d t=0$ and $d t=+1$, while the lowest value was recorded when $d t=$ -1 .

5- Infrared thermometer can be used for determination irrigation scheduling.

\section{REFERENCES}

Abdolreza, E. N., E.M. Esfahani, M. B., Harchegani, $M$. Jafarpour and $M$.
Golabadi (2014). Leaf temperature as an index to determine the irrigation interval.Research on Crop Ecophysiology. 91 (2): 89-95.

Attia, M. M. (1989). Effect of water stress, nitrogen fertilization and soil conditioners on water requirements ofcorn, wheat, soybean and lentil in North Delta RegionPh.D Thesis Fac. Agric. Alex. Univ. Egypt. Bijanzadeh, E. and Y. Emam, (2012). Evaluation of crop stress index canopy temperature and grain yield of five Iranian wheat cultivars under late season drought stress. Journal of plant physiology and breeding, 2(1): 23:33.

Blum, A., L. Shpiter, G. Golan and J. Mayer (1989). Yield stability and canopy temperature of wheat genotypes under 
drought stress. Field Crop Res., 22:289296.

Ehsan, B. and Y. Yahya (2012). Evaluation of crop water stress index, Canopy temperature and grain yield of five Iranian wheat cultivars under late season drought stress. Journal of plant physiology and Breeding 2(1): 23-33.

Guofu, Y., Yiluo, X. Sun and D. Tang (2004). Evaluation of crop water stress index for detecting water stress in winter wheat in the Notth China Plain, Agricultural Water Management 64: 29-40.

Hansen, V.E., O.W. Israelsen and G.E. Stringham (1974). "Irrigation Princiles" $4^{\text {th }}$ Ed. John Wiley Sons. New York.

Inagaki, M.N. and M. M. Nachit (2008). Visual monitoring of water deficit stress using infrared hermography in wheat.The $11^{\text {th }}$ International wheat Genetics Symposium Proceedings Edited by Rudi Apples Russell Eastwood Evans Lagudah Peter Langridge Michael Mackay Lynne.

Jackson, R. D., S. B. Idso, R. J. Reginato and J. P. Pinter (1981). Canopy temperature as a crop water stress indicator. Water Resources Research 17 (4), 1133-1138.

Jackson, R. D. (1982). Canopy temperature and crop water stress. Advances in Irrigation, Vol. 1. Academic Press, New York.
Jalali-Farahani, H.R., D.C. Slack, D.M. Kopec and A.D. Matthias (1993). Crop water stress index models for bremudagrass. Agronomy Journal 85:1210-1217.

Jensen, M. E. (1983). "Design and Operation of Farm Irrigation Systems". Am. Soc. Ag. Eng. Mitchigan U.S.A, PP.827.

Kim, M., K. Seounghee, K. Yougjin, C. Yonghun and S. Myungchul (2015). Infrared estimation of canopy temperature as crop water stress indicator. Korean Journal of soil science and fertilizer, 48 (5): 499-504.

Orta, A.H., I. Baser, S. Sehirali, T. Erdem and Y. Erdem (2004). Use of infrared thermometry for developing baseline equations and scheduling irrigation in wheat. Cereal Research Communications 32(3), 363-370.

Page, A.L. R.H miller and D. R. Keeny (1982). Methods of soilanalysis. Am Soc. Agr.Inc., Madison, WI, USA.

Reynolds, M.P., C. S. Pierre, S.I Saad, M. Vargas and A.G. Condon (2007). Evaluating Potential Genetic Gains in Wheat Associated with Stress - Adaptive Trait Expression in Elite Genetic Resources under Drought and Heat Stress, Crop Sci. 47: 172-189.

Stel, R.G. and J.H. Torrie (1980). Principals and Procedures of Statistics. $2^{\text {nd }}$ Edi Now York, Mc. Grow Hill Book company.196p.

$$
\begin{aligned}
& \text { جدولة رى محصول القمح باستخدام جهاز الحرارة بالأشعة تحت الحمراء } \\
& \text { محمود محمد عطية(1) ، أحمد عبدالهادى سلام(1) ، الحسيني غلاب جلال)(2) }
\end{aligned}
$$

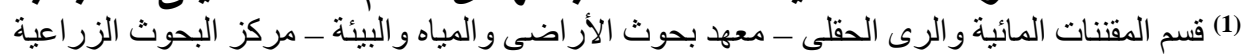




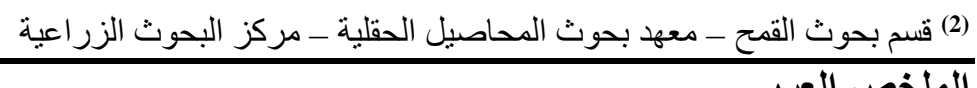

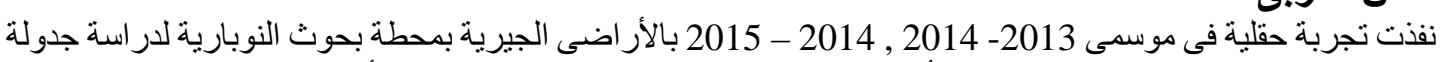

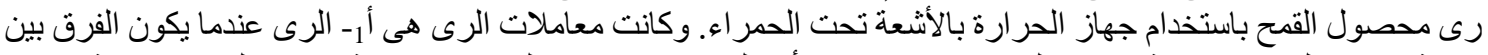

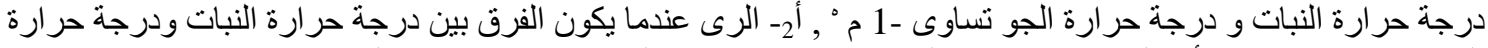

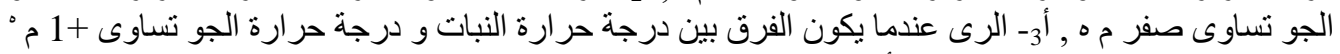

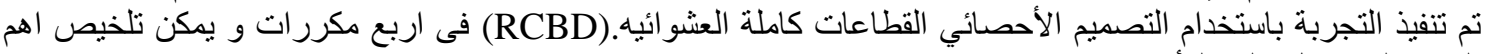

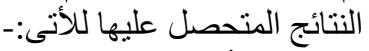

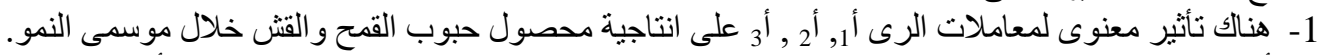

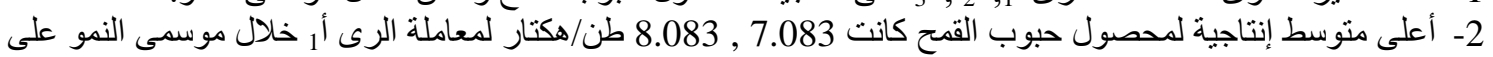

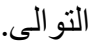

3- أنسب كمية مياه مضافة كانت 42.1 , 42.4 , 41.7 سم لمعاملة الرى أي خلال موسمى النمو على التو الى الى.

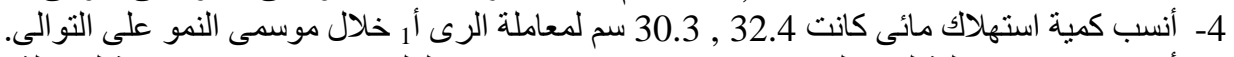
5- أنسب كفاءة إستعمالية لمياه الرى كانت 1.68 , 1.93 كجم قمح لكل متر مكعب مياه مضافة لمعاملة الرى أل خلال موسىى النمو.

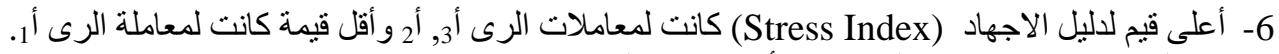

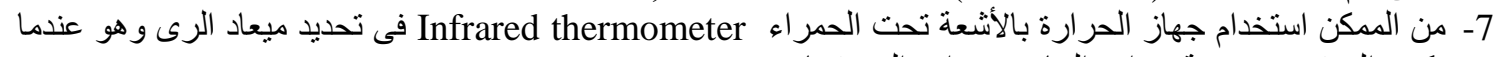

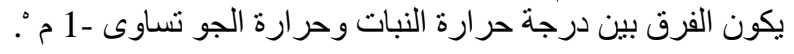

